\title{
Acquisition Entry Strategy of Nordic Multinational Enterprises in China: An Analysis of Key Determinants \\ Authors:
}

1. Ahmad Arslan, Business School, Edge Hill University, Ormskirk, Lancashire.

Email: arslana@edgehill.ac.uk

2. Yi Wang, Department of Marketing, University of Vaasa, Finland.

Email:wyi@uva.fi

\begin{abstract}
This paper addresses the key determinants of acquisition entry strategy (i.e. the choice between full vs. partial acquisition) of Nordic multinational enterprises (MNEs) in China. Although, general establishment and entry mode strategies have been a highly researched area in international business (IB) studies, acquisitions as a specific entry strategy and its different aspects have been scarcely researched. Therefore, the current study aim to fill the gap in literature by analyzing determinants of acquisition entry strategy based on three important theoretical bases, i.e. transaction cost economics, resource-based view and institutional theory. The current paper is also first study to analyze acquisition entry strategy of MNEs from all four Nordic economies (Denmark, Finland, Norway and Sweden) in China during 1987-2012, and this unique empirical context adds further value to the study findings. The empirical results show that high target country experience, high cultural distance, high level of product diversification and subsidiary location in institutionally developed and open cities of China were positively associated to choice of full acquisitions by Nordic MNEs. On the other hand, high industry R\&D intensity, and timing of acquisition lead to the choice of partial acquisitions by the investing Nordic MNEs.
\end{abstract}

Keywords: Foreign Market Entry, Full acquisition, Partial acquisition, China, and Nordic Multinational Enterprises

This is an Accepted Manuscript of an article published by Taylor \& Francis in JOURNAL OF GLOBAL MARKETING on $6^{\text {TH }}$ November, 2014, available online at http://dx.doi.org/10.1080/08911762.2014.965865

Please cite this paper as: Arslan, A., \& Wang, Y. (2015). "Acquisition Entry Strategy of Nordic Multinational Enterprises in China: An Analysis of Key Determinants". Journal of Global Marketing, 28:1, 32-51. 


\section{INTRODUCTION}

Foreign direct investment (FDI) strategy of multinational enterprises (MNEs) is one of the most important and often researched topics in international business (IB) and management studies (Brouthers \& Hennart, 2007; Slangen \& Hennart, 2008; Demirbag et al., 2008, 2009). MNEs face two important strategic questions while deciding their market entry FDI strategy; firstly, whether to acquire an existing enterprise (acquisition) or establish a new start up from scratch (greenfield investment) and secondly, whether to form wholly owned subsidiary (WOS) or a joint venture (JV) with local partner (Brouthers \& Brouthers, 2000; Dikova \& van Witteloostuijn, 2007; Slangen \& Hennart, 2008; Arslan \& Larimo, 2011). IB researchers have analyzed FDI entry strategies of MNEs using a variety of theoretical and empirical approaches as well as concentrating on different aspects of these strategies.

Some past studies analyzed the choice between greenfield investment and acquisition entry strategy by the investing foreign MNEs (e.g. Hennart \& Park, 1993; Brouthers \& Brouthers, 2000; Datta et al., 2002; Larimo, 2003; Shimizu et al., 2004; Slangen \& Hennart, 2008; Demirbag et al., 2008, 2009; Arslan \& Larimo, 2011). Other IB studies addressed the ownership mode strategy of MNEs by studying the choice between WOS or a JV formation (e.g. Anderson \& Gatignon, 1986; Luo, 2001; Brouthers \& Hennart, 2007; Jung et al., 2008; Arslan \& Larimo, 2010). However, the literature review reveals that very few IB and market entry studies (e.g. Jakobsen \& Meyer, 2008; Arslan \& Larimo, 2012) have analyzed acquisition entry strategy of MNEs specifically by differentiating between full acquisitions vs. partial acquisitions, in case the MNE decides to acquire a local firm at time of market entry in a new target country. Although, some previous studies mention that acquisitions can be difficult to manage compared to greenfield investments (e.g. Datta et al., 2002; Slangen \& Hennart, 2008), but acquisitions have also been found suffer less from liability of foreignness and newness compared to the greenfield subsidiaries (e.g. Pablo \& Javidan, 2004). Therefore, acquisitions can be presumed as a preferred entry strategy of investing MNEs in

order to gain relatively quick foothold in local market by accessing needed local networks, as well as avoid problems associated with liability of foreignness and newness associated with a greenfield subsidiaries established by foreign MNE (Arslan \& Larimo, 2012). 
It is also important to refer that lack of studies differentiating between full and partial acquisition in past explains the variance in findings of studies addressing establishment and ownership mode strategies of MNEs (e.g. Chen, 2008; Jakobsen \& Meyer, 2008). As a result, important features that are unique to acquisition entry strategy have been ignored in previous IB studies due to the tendency to analyze full and partial acquisitions together whether those studies addressed the establishment mode or ownership mode strategies of MNEs (Chen, 2008; Chen \& Hennart, 2004). Full acquisitions offer unified ownership of the target and majority control rights to exploit and integrate the combined resource base, while partial acquisitions offer limited ownership and minority control rights (Chen, 2008). Although, full acquisitions require high investments in human, physical and intangible assets, and greater overall commitment, they also offer the advantage of full control over acquired firm for the foreign MNE. On the other hand, partial acquisitions require rather limited resource commitments and control mechanisms and are prone to less transaction and governance costs but higher internal organizational costs (Chen \& Hennart, 2004; Chen, 2008). Moreover, the foreign MNEs opting for partial acquisition entry strategy retain the flexibility of enhancing equity stake in their targets, as they continue to accumulate post-acquisition market knowledge and the acquired business entity (Shimizu et al., 2004). However, as mentioned earlier that previous studies have scarcely analyzed full vs. partial acquisition choice in detail, though acquisition entry strategy is increasingly popular in many emerging economies due to market economy reforms and removal of restrictions on acquiring local firms (Lin, 2000; Chen, 2008; Arslan \& Larimo, 2012). Therefore, the current paper aims to fill that gap in IB literature by concentrating on the choice between full and partial acquisition of the MNEs and analyzing the key determinants of this important market entry strategy of MNEs.

It has been referred by the scholars that IB as a research area is multidisciplinary in nature, where many theoretical perspectives are applicable (Brouthers \& Hennart, 2007; Slangen \& Hennart, 2008). Moreover, IB entry mode decisions and strategies have been analyzed in many cases by using multiple theoretical frameworks, with transaction cost economics (TCE), resource-based view (RBV) and institutional theory emerging as the most often and commonly used ones (Meyer \& Peng, 2005; Brouthers \& Hennart, 2007; Slangen \& Hennart, 2007; Larimo \& Arslan, 2013). Therefore, our paper tries to analyze the key determinants of acquisitions entry strategy of MNEs based on TCE, RBV and institutional theory. Our choice of using all these theories together is 
further signified by the fact that TCE, RBV and institutional theory have been operationalized by a similar range of variables in the past IB and market entry mode analysis studies (e.g. Claver \& Quer, 2005; Brouthers and\& Hennart, 2007; Dikova \& van Witteloostuijn, 2007; Dikova et al., 2010; Arslan \& Larimo, 2010, 2011, 2012; Demirbag et al., 2011; Dikova, 2012; Larimo \& Arslan, 2013). Consequently, we also deem it important for our study concentrating on acquisition entry strategy of the firms to integrate theoretical arguments from all three above mentioned theories. Our study attempts to adapt a rather comprehensive approach, and consequently, it theoretically advances market entry literature as it is one of the first to hypothesize and analyze different key determinants of acquisition entry strategy of MNEs.

The empirical part of the study uses a relatively unique sample of the acquisitions made by the MNEs originating in Denmark, Finland, Norway and Sweden (i.e. Nordic economies) in the Chinese market in order to test the hypotheses. The literature review reveals that earlier Arslan and Larimo (2012) analyzed acquisition entry strategy of MNEs from Nordic region. However, they only concentrated on institutional pressures as being key determinant and their empirical sample was limited to acquisitions by only Finnish MNEs in different emerging economies. We believe that use of Nordic sample in our study as well as theoretical diversity enhances the study's values as well as increases the generalizability of the findings. It should be noted that since China opened its door to foreign investments in 1979, there has been a rapid growth of FDI inflows as well as MNE operations there (Lin, 2000; Huang, 2008). As a result, China is now among one of the top FDI recipients in the globe and is the biggest foreign investment destination in Asia. Moreover, as Chinese government removed restrictions on acquisitions (both full and partial acquisitions) of local firms, the number of acquisitions by foreign MNEs using acquisitions as entry mode has increased as depicted in the following figure 1. Therefore, this unique empirical context further enhances the contribution of our study as it well as enhances interest for both academic and managerial audience.

\section{Insert Figure 1 here}

Our paper starts with brief theoretical discussion leading to the development of study hypotheses. The next section addresses methodology, data and sample discussion followed by analysis and 
discussion of study findings. The paper concludes with discussion concerning study limitations as well as managerial implications and future research directions.

\section{THEORETICAL DISCUSSION AND STUDY HYPOTHESES}

Past IB studies mention that several firm, industry and target country related variables are important for both FDI establishment and ownership mode strategies of the MNEs (Luo, 2001; Slangen \& Hennart, 2008; Morschett et al., 2010). It has been mentioned earlier in the current paper that most of the previous market entry studies have used TCE, RBV and institutional theory to analyze FDI ownership mode choices of the firms. Meyer and Peng (2005) in their review paper concentrating on management and IB strategies in transition economies also found that mostly these three theories were used by the researchers analyzing market entry mode strategies. They further observed that due to specific nature of changes in transition economies, there is a need by the researchers to adopt more comprehensive theoretical approach by integrating arguments from these theories while analyzing different IB and market entry strategies. We also support this observation by arguing that it is important to integrate key determinants of acquisition entry strategy of MNEs in important and economically attractive emerging economy of China. So far, no previous research (at least to our knowledge) concentrating on China has analyzed the key determinants of acquisition entry strategy based on these three theoretical bases, i.e. TCE, RCV and institutional theory. It is further important to note that certain variables like $R \& D$ intensity, international experience, target country experience, economic growth, degree of product diversification, cultural distance, transition and institutional advancement in the target country have been used as key indicators in studies that utilized TCE, RBV as well as institutional theory as their theoretical bases for entry mode related choices analysis (see e.g. Hill et al., 1990; Claver \& Quer, 2005; Dikova \& van Witteloostuijn, 2007; Arslan \& Larimo, 2010, 2011, 2012; Demirbag et al., 2008, 2009, 2011; Dikova, 2012; Larimo \& Arslan, 2013). Therefore, we have incorporated these determinants found significant in past IB studies in our analysis by addressing them together in the context of acquisition entry strategy of the Nordic MNEs in China.

We present the relevant theoretical discussion that leads to development of study hypotheses in relation to full vs. partial acquisition choice of Nordic firms in China as follows. 
Industry R\&D intensity: Research and Development (R\&D) intensity has been used in past IB studies using TCE as theoretical base to address the concept of asset specificity (Zhao et al., 2004). It has been established in past IB literature that MNEs with a high level of R\&D intensity are likely to exploit significant amount of knowledge to international markets (e.g. Slangen \& Hennart, 2007). This knowledge is also an integral part of RBV, where Barney (1991) referred to importance of knowledge in firm's strategies both domestic and global.

It should be further noted that MNEs operating in industry with high level of R\&D intensity are likely to transfer significant amount of knowledge to their subsidiaries. However, if these subsidiaries are the result of acquisition of local firms, then the management problems can be significant for foreign MNEs (Hennart \& Park, 1993; Drogendijk \& Slangen, 2006). The foreign MNEs can be further expected to face great difficulties in pricing the technology and enforcing the contracts in case of a joint establishment (Anderson \& Gatignon, 1986; Hennart, 1991) i.e. partial acquisition, in case of market entry via acquisition mode. Past literature further establishes that MNEs with high R\&D expenses tend to prefer full ownership in order to completely control their proprietary know-how as well as best exploit such know-how in their international markets (e.g. Padmanabhan \& Cho, 1996). The results of past IB studies specifically focusing on China further support the view that high industry $\mathrm{R} \& \mathrm{D}$ intensity tend to increase the probability of firms to choose full ownership rather than shared ownership in their subsidiaries (Chiao et al., 2010; Huang, 2008). We argue in the current paper that for a Nordic MNE operating in high R\&D intensity industries, full acquisition is more preferable option that partial acquisition in case it uses acquisition as entry mode to China. Therefore, we hypothesize

Hypothesis 1: High industry R\&D intensity is positively associated with the propensity of Nordic MNEs to choose full acquisitions in China.

International experience: Knowledge about how to successfully operate internationally is tacit in nature and is largely developed through experience (Johanson \& Vahlne, 1977). This kind of knowledge can be considered an essential part of RBV as it plays a major role in international performance of MNEs. International experience has been referred to as an important factor in the entry mode choice by many MNE studies (e.g. Gatignon \& Anderson, 1988; Hennart, 1991; 
Brouthers \& Brouthers, 2001; Brouthers \& Hennart, 2007). The familiarity with the target country or other similar international markets can reduce MNEs' uncertainty (Johanson \& Vahlne, 1977; Meyer \& Tran, 2006), and can also influence acquisition strategy. However it is important to note that past IB studies have reported mixed findings with regard to the effect of international experience on entry strategy of MNEs. Several studies such as Padmanabhan \& Cho (1999), Shi et al. (2001), Claver \& Quer (2005) and Arslan \& Larimo (2010) have indicated non-significant relationship between international experience and choice of ownership. However, in some China specific studies, international experience has been found to be positively associated with the probability of Taiwanese firms to choose full ownership (e.g. Chiao et al., 2010). We argue in this paper that in case the internationally experienced Nordic MNEs choose acquisition as entry mode to China, full acquisition appears as more probably option than the partial acquisition because operations in multiple markets develop a general structural ability to adapt (Tallman \& FladmoeLindquist, 2002) as well as manage the idiosyncrasies of new international markets (Delios \& Henisz, 2003; Eden \& Miller, 2004). Therefore, we hypothesize:

Hypothesis 2: High international experience is positively associated with the propensity of Nordic MNEs to choose full acquisitions in China.

Target country experience: Previous IB studies using both TCE and RBV theories referred to the importance of host country experience also along with general international experience for the analysis of market entry mode strategy of the MNEs (e.g. Dowell \& Killaly, 2009). Foreign MNEs with no or relatively less experience of operations in a particular market tend to lack the knowledge of local conditions (Hennart, 1991). Local firms develop and accumulate this market knowledge through doing business in the local market as well as understanding local market conditions and dynamics clearly. Local market knowledge is therefore embedded in the local firm and is costly to replicate or to purchase (Hennart \& Park, 1993). Past IB studies also refer that MNEs with prior investment experience in the target country tend to accumulate such knowledge and therefore tend to be less dependent on local partner. Consequently, these firms are less likely to share the ownership of the subsidiary with local partners (Arslan \& Larimo, 2010); thereby increased preference of full acquisition in case of using acquisition entry strategy. Hennart (1991) found that Japanese investors having greater target country (U.S in this case.) experience are more likely to 
choose full ownership over shared ownership. Moreover, several past China-focused empirical IB studies (Luo, 2001, Claver \& Quer, 2005 Wei et al., 2005) also found full ownership of the Chinese subsidiary of MNEs linked to high host country experience. As, there is no previous study specifically analyzing acquisition entry strategy of MNEs in China in relation to host country experience, we follow the logic presented by above mentioned past ownership focused IB studies. Therefore, based on the above discussion, we hypothesize:

Hypothesis 3: High target country experience is positively associated with the propensity of Nordic MNEs to choose full acquisitions in China.

Cultural distance between home and target country: Cultural distance has been referred as the difference in national culture characteristics of the home and of the host country in IB studies (Hennart \& Larimo, 1998). In general, the larger the cultural distance between the home and host country, the more costly it is for MNEs to transfer intangible assets such as organizational and managerial practices to their subsidiaries located in host country (Slangen \& Hennart, 2007). Acquisitions in culturally distant countries offer certain advantages like less liability of foreignness (Eden \& Miller, 2004), as well as costs associated with post acquisition integration of workforce used to different practices (Arslan \& Larimo, 2011). The relationship of cultural distance and entry strategies can be analyzed in the context of investing foreign MNE's need for the risk reduction by several past IB studies (e.g. Kogut \& Singh, 1988; Tihanyi et al., 2005). From this perspective, the MNEs operating in culturally distant target countries often require greater flexibility in their strategies as well as operations, which can be achieved via shared ownership arrangement with a local partner (Tihanyi et al., 2005). Moreover, in China-focused past studies, Sun (1999) and Wei et al. (2005) found empirical supports for the negative association between cultural distance and choice of full ownership. Further on, in studies by Luo (2001) and Chen and $\mathrm{Hu}$ (2002), cultural distance is found to be non-significantly associated with entry strategy of investing firms in China. As, there is no previous IB study specifically analyzing acquisition entry strategy of MNEs in China and the influences of cultural distance on it, we follow argumentation of above mentioned past establishment and ownership strategy focused IB studies. Therefore, based on the above discussion, we hypothesize: 
Hypothesis 4: High cultural distance is negatively associated with the propensity of Nordic MNEs to choose full acquisitions in China.

Economic growth in the target country: The attractiveness of a target market is an important indicator of FDI flow as well as key determinant of FDI strategies of investing MNEs in a particular economy according to TCE (Hennart, 1982, 1991; Larimo \& Arslan, 2013). In past IB studies, the attractiveness of target market has been conceptualized using economic growth in that target country (e.g. Hill et al., 1990; Hennart \& Larimo, 1998; Meyer \& Peng, 2005; Arslan \& Larimo, 2010). Following TCE reasoning, high economic growth in the target country should motivate the investing MNEs to opt for full ownership (Morschett et al., 2010) i.e. full acquisitions, in case acquisitions are used as entry strategy. In past IB studies focusing specifically on China Lu, Karpova and Fiore (2011) pointed out that economic growth in China increased the probability of foreign MNEs to opt for full ownership. Finally, the only study specifically analyzing acquisition entry strategy of firms from Nordic region also found a positive relationship between the choice of full acquisition and high economic growth in the target country (Arslan \& Larimo, 2012). Based, on the above discussion, we hypothesize

Hypothesis 5: High target country economic growth is positively associated with the propensity of Nordic firms to choose full acquisition in China.

Degree of product diversification: A key issue addressed in TCE as well as RBV is uncertainty which has been found to influence different market entry strategies of MNEs (e.g. Mudambi \& Mudambi, 2002; Larimo, 2003; Tihanyi et al., 2005; Slangen \& Hennart, 2008; Dikova, 2012). In order to reduce the uncertainties associated with foreign market entry, IB literature refers to the degree of product diversification of MNEs which is also an important indicator for their market entry strategies (e.g. Mudambi \& Mudambi, 2002; Tihanyi et al. 2005; Larimo \& Arslan, 2013). Firm's product diversification is generally defined using 3-digit or 4-digit Standard Industrial Classification (SIC) codes (Palepu, 1985; Mudambi \& Mudambi, 2002; Larimo \& Arslan, 2013).

Past IB studies have referred that diversification offers MNEs the opportunities to obtain new resources and transfer their core competencies to new markets (Bartlett \& Ghoshal, 1989; Kobrin, 
1991). These benefits tend to result in higher MNE performance and positive returns (Gomes \& Ramaswamy, 1999). It has been referred in IB studies that the highly concentrated firms more commonly own the needed product-specific knowledge (Burget \& Murray, 2000). Therefore, based on TCE reasoning, there is less need for a partner in foreign subsidiaries of such MNEs because they have the required knowledge top operate their core businesses (Larimo \& Arslan, 2013). When the degree of diversification of the MNEs increase, the lack of product-specific knowledge in different industries of their operations becomes evident which increases importance of having a partner in subsidiary management. Such product-specific knowledge is experiential and largely tacit (Slangen \& Hennart, 2007), and therefore it is costly to replicate such knowledge internally and hardly to purchase in market (Hennart, 1991). Therefore, it can be expected that the firms having more diversified operations may find partial ownership mode being more efficient tool to access such product-specific knowledge as mentioned in the studies (e.g. Mudambi \& Mudambi, 2002; Tihanyi et al., 2003). The impact of degree of diversification on acquisition entry strategy has not been analyzed in any past IB studies. However, based on the discussion presented above, we hypothesize that

Hypothesis 6: High degree of product diversification of investing MNEs is negatively associated with the propensity of Nordic firms to choose full acquisition in China.

Market economy institutional advancement and timing of acquisition: FDI strategies of internationalizing firms are considerably influenced by the development and effectiveness of market economy institutions of their host countries (e.g. Peng, 2003; Meyer \& Peng, 2005; Peng \& Khoury, 2009). An important issue to note while analyzing MNEs' entry strategies in emerging economies like China related to timing as they have had different levels of market economy institutional development during different time periods (Peng, 2003; Peng et al., 2008). During the early phase of transition and development of market economy, China was characterized by government intervention for business operations, lack of reliable business information and weak intellectual property protection (Lin, 2000; Luo, 2001; Wei et al., 2005; Chung \& Beamish, 2005). Moreover, during early stages of transition, Chinese government also tended to discourage and restrict acquisitions and full ownership modes in most industries, while offering incentives for greenfield joint establishments (Lin, 2000; Huang, 2008). However, in later phase of transition, the 
market economy institutions strengthened as well as restrictions on acquisitions by the foreign MNEs slowly reduced that even some foreign MNEs were able to acquire some state-owned enterprises (SOEs) (Norton \& Chao, 2001). SOEs in China were suffered from low efficiency and huge losses. The policy of "grasp the large, release the small" in China allowed foreign investors to acquire small and medium sized (SMEs) Chinese enterprises as Chinese government imposed relatively little control over private enterprises since late 1990s, MNEs had a greater opportunity to acquire private enterprises in China (Teng, 2004).

The previous IB literature shows clearly that restrictions on level of foreign ownership tend to discourage full ownership modes by the investing MNEs (e.g. Gomes-Casseres, 1989, 1990; Makino \& Beamish, 1998; Delios \& Beamish, 1999; Arslan, 2012). On the other hand, the results by Child and Tsai (2005) indicate that when firms operate favorable external circumstances, they tend to commit more resources to the target country and may prefer the formation of wholly owned establishments (whether greenfield investments or acquisitions). In case of China, the gradual transition to market economy is also expected to result in increased acceptance and legitimacy for fully foreign owned establishments ( $\mathrm{Li}$ et al., 2007). Based on the above discussion, we argue in this paper that in later phases transition (2002-onwards, based on China's accession to WTO in 2001), full acquisitions are more probable compared to early phases (pre-2002) due to strengthening of market economy institutions and lesser restrictions in China. Therefore, we hypothesize that

Hypothesis 7: Timing of acquisition is negatively associated with the propensity of Nordic firms to choose full acquisition in China.

Subsidiary location: There is a considerable difference in restrictions on operations of foreign MNEs and institutional development in different regions of emerging economies (Peng et al., 2008). In case of China, a key feature of development of market economy has been the growth of open cities/special economic zones, where the restriction of foreign MNEs tended to be far lower than the rest of the country (Lin, 2000; Luo, 2000). In 1980, China designated Shenzhen, Zhuhai and Shantou within Guangdong province and Xiamen within Fujian province as Special Economic Zones (SEZs). The intention of the Chinese government was to use SEZs to attract foreign 
investments, expand exports and infusion of advanced technology. SEZs were encouraged to implement pragmatic and open economic policies. Because of the success of the SEZs, in 1984, Chinese government decided to further open its economy by extending similar policies to fourteen coastal cities. In 1985, the open cities were extended to Pearl River Delta, the Yangtze River Delta and Min Delta in Fujian. In 1988, the entire Hainan province was designated as a fifth special economic zone. In order to further attract foreign investments in Yangtze River Delta, Shanghai Pudong new district was created in 1990 (Yeung et al., 2009).

World Bank survey of 120 Chinese cities (2006) have shown that both of the overall investment climate and local government effectiveness and efficiency in SEZs and open coastal cities were ranked in the top quintile of all surveyed cities. On the other hand, the quintile of cities ranked lowest was all located within inland of China. In addition, MNEs operating in SEZs/open coastal cities receives preferential corporate tax rate, which was generally lower than other enterprises. Moreover, although laws and regulations were consistent at the nation level, the time spent on interactions with the local government differed across regions. Compared to foreign firms operating in interior cities in China, MNEs doing business in SEZs/open coastal cities spend less time with local government. In past China focused studies, Sun (1999), Luo (2001) and Wei et al. (2005) found the empirical supports for the positive relationship between subsidiary located in SEZ/open coastal cities and the choice of full ownership mode. As there are no prior studies specifically linked subsidiary location with full vs. partial acquisitions, we follow the augments and discussions presented by the above mentioned earlier China focused studies. Therefore, we propose that:

Hypothesis 8: Subsidiary location in SEZs/open coastal cities is positively associated with the propensity of Nordic firms to choose full acquisition in China. 


\section{METHODOLOGY, SAMPLE, AND OPERATIONALIZATION OF VARIABLES}

\subsection{Statistical method}

Since, the dependent variable in this study is dichotomous (i.e. full vs. partial acquisition), binary logistic regression analysis was employed to analyze the impact of the selected variables on the acquisition entry strategy of Nordic MNEs. Binary logistic regression has been used often as a reliable statistical analysis technique in past IB studies addressing different aspects of entry mode strategies generally (e.g. Hennart \& Larimo, 1998; Larimo, 2003; Dikova \& van Witteloostuijn, 2007; Kaynak et al., 2007; Demirbag et al., 2009) as well as acquisition entry strategy of MNEs specifically (e.g. Arslan \& Larimo, 2012). Therefore, the current study also employs binomial logistic regression for the statistical analysis of acquisition entry strategy of Nordic MNEs in China.

Binomial logistic regression model is formally expressed as

$$
P(y i=1)=1 / 1+\exp (-a-X i B)
$$

Where $y i$ is the dependent variable, $\mathrm{Xi}$ is the vector of independent variables for the ith observation, $a$ is the intercept parameter and $B$ is the vector of regression coefficients (Amemiya, 1981). The recent version of SPSS i.e. PASW 21 is used for the binomial regression analysis in this study. The dependent variable has been coded with value 1 for full acquisition; therefore, therefore a positive regression coefficient indicates that a particular independent variable increases the probability of full acquisition choice by the investing MNEs.

\subsection{Sample description}

The empirical data for the study is based on the internal FDI consisting of FDI activities of Nordic MNEs. This databank has been developed and continuously updated since many years by the departmental researchers working on these research areas. It is based on stock exchange movements, the annual reports and press releases of the investing MNEs, but also supplemented with the data gathered from articles in leading local business magazines as well as direct contact with several of the investing MNEs. 
We identified 413 FDIs made by Nordic MNEs in China during 1987-2012. 106 out of 413 FDIs are acquisitions, while 307 investments are greenfield startups. As, the study aims to address the acquisition entry strategy, our sample consists 106 acquisitions made in manufacturing sector made by 65 Nordic MNEs in China during 1987-2012.

Table 1 offers detailed characteristics of study sample by indicating the ownership structure, country of origin of acquiring MNEs, industries of operations, industry R\&D intensity, parent MNEs' international and target country experience, timing of investment and subsidiary location.

\section{Insert Table 1 here}

The table 1 shows that $62.3 \%$ of the investments were partial acquisitions, while $37.7 \%$ were full acquisitions. More than half of the acquisitions were made between 2002 and 2012, which is in line with increased activities of foreign MNEs in China, after it accession to WTO in 2001. A large proportion $(68 \%)$ of the investments was located in the SEZs/open coastal cities. The sample included investments made in all two digit manufacturing industries (SIC 20-39), but almost 70\% the sample were investments made in SIC 20 (food), SIC 26 (paper and paper related products), SIC 28 (chemicals), SIC 35 (machinery), and SIC 36 (electronics).

\subsection{Operationalization of variables}

The dependent variable in this study is captured by a dummy variable which receives one if the firm owned $80 \%$ or more of the subsidiary equity and zero if it owned at least $20 \%$, but no more than $80 \%$. The $80 \%$ cut-off point was used in several earlier studies (Delios \& Makino, 2003; Papyrina, 2007). For the independent variables, research and development intensity is a categorical variable, where 1 stands for low-tech branch, 2 for medium-tech branch and 3 for hightech branch. International experience was measured by the number of foreign manufacturing investments preceding a subsidiary's establishment. Target country experience was measured by the number of years since the first manufacturing investment of the parent firm in China. We measured cultural distance by Kogut and Singh (1988) composite index, which is based on is based on difference between four Nordic countries and China along four dimensions of culture identified 
by Hofstede (1990). Economic growth was operationalized by GDP in the preceding year of the establishment of the subsidiary. Degree of product diversification of the investing MNEs was measured by the number of four-digit SIC codes in which the company was operating. A dummy variable was created for measuring timing of acquisitions, where 1 stands for investments made pre 2002 and 0 for investments made after 2001. Subsidiary location was measured by a dummy variable, where investments located in SEZs and / or open coastal cities were coded as 1 and investments made in other parts of China were given as 0 . The operationalization of the independent variables, data sources, examples of earlier studies where similar operationalization has been used and expected signs are presented in Table 2.

\section{Insert Table 2 here}

In addition to the selected independent variables, we added five control variables: industry resource intensity, industry restrictions, industry concentration, industry sales growth and parent MNE size. We create a dummy variable which stands for one if the subsidiary's main products are in a resource-intensity industry, i.e., food and beverage, textile, wood except furniture, paper and paper related products, rubber, stone and glass, and primary metals (Hennart, 1991), and zero for other industries. A dummy variable where 1 stands for restricted manufacturing business segments, i.e., production of complete cars, ordinary bearings and transformation and transmission systems and 0 for otherwise. In transition economies like China, both wholly-owned subsidiaries and acquisitions have been long restricted in strategic important industries (Teng, 2004). We therefore expect that industry restrictions should be negatively associated with full acquisitions. In past entry mode studies, scholars found that industry structures such as industry concentration and industry sales growth are important determinants of entry mode strategy of MNEs (Hennart \& Park, 1993; Tihanyi et al., 2005; Dikova \& van Witteloostuijn, 2007). Highly concentrated industries in transition economies like China signal greater government interventions and therefore the business opportunities in these industries are relatively less (Luo, 2001). Hence, the level of concentration should be negatively associated with the choice of full acquisitions. When the potential for sales in a particular industry is more stable and certain, parent MNEs are more likely to commit more resources (Luo, 2001). We therefore expect that industry sales growth increase the use of full acquisitions. The information of industry sales and number of firms in a given industry is drawn 
from China Statistical Yearbook (1988-2009). Industry sales growth and industry concentration are calculated using the compound growth rate over three consecutive years prior to the establishment of the subsidiary (Luo, 2001). Further on, parent MNE size is measured by worldwide annual sales of the company (in million euros) in the year preceding the investment. Since large MNEs are able to provide adequate financial resources (Padmanabhan \& Cho, 1996) and to absorb risk (Taylor et al., 1998), the sign of parent MNE size should be positive.

\section{RESULTS}

Before running the logistic regression, a correlation analysis (see appendix) was conducted to detect any multicollinearity between various variables. A correlation analysis is conducted before logistic regression tests in order to detect any multicollinearity among independent variables. Following Belsley et al. (1980) and Pallant (2007), additional multicollinearity diagnostic (tolerance and variance inflation factor (VIF)) was also conducted. According to Wetherill (1986), the VIF values for independent and control variables used in regression analysis should not exceed 10. In our study, the VIF values are lower than 5 and thus, the potential multicollinearity among independent and control variables is not expected to influence the results of logistic regression analysis.

Table 3 displays the results of binomial regression analysis for acquisition entry strategy of Nordic MNEs China. The explanatory power of the regression model is good, as the chi-square $\left(\mathrm{x}^{2}\right)$ value is highly significant at $\mathrm{p} \leq 0.01$ level. The predictive strength of the statistical models can be assessed by the correct classification rate. Regression model of our study has a higher correct classification rate than the chance rate of $52.8 \%$, which is calculated using the proportional chance

criterion which is $a^{2}+(1-a)^{2}$, where $a$ is a proportion of full acquisitions (38\%) in our sample. The regression model of the study has correct classification rate $70.8 \%$; therefore $18 \%$ increase in correct classification rates. Finally, good Nagelkerke $\mathrm{R}^{2}$ value of 0.340 also depicts rather significant predictive capability of our regression model.

The study results show that out of chosen control variables, three are significant. Industry resource intensity is positively and significantly $(\mathrm{p} \leq 0.05)$ associated with the probability of Nordic MNEs 
to choose full acquisitions in China. Further on, the regression analysis shows that Nordic MNEs with subsidiaries in restricted manufacturing industries is significant at $\mathrm{p} \leq 0.10$ level. The negative coefficient of industry restrictions suggest that Nordic MNEs prefer partial acquisitions when entering into strategically important industries. This is consistent with our expectation, as foreign firms are not able to own subsidiaries fully in those industries in China. Our results further indicate that high growth industries tend to increase the probability of Nordic MNEs to choose full acquisitions $(\mathrm{p} \leq 0.05)$. This finding is consistent with our expectation that high industry sales encourage parent MNEs to choose full acquisitions to retain more profits in China, as well as show commitment for long term presence in this important market. Although, the coefficients of industry concentration and parent MNE size were not significant, the signs indicate that high number of firms and large parent MNEs increase the choice of full acquisitions.

\section{Insert Table 3 here}

The regression results further depict that industry $R \& D$ intensity is mildly significant at $p \leq 0.05$ level and the regression coefficient depicts that in industries with high R\&D intensity, partial acquisitions have been preferred by Nordic MNEs. This finding is opposite to our hypothesis 1 . However, we would like to mention that previous IB studies addressing this issue analyzed FDIs made in developed market economies, which are full of suitable acquisition targets (Hennart \& Park, 1993), as well as full acquisitions are not restricted based on industry's importance for the country. However, in case of China, certain industries (mostly technological and research intensive) have long been labeled as strategic industries where Chinese government wanted to develop local competencies via knowledge and technology transfer (Huang, 2008). Therefore, full ownership of foreign MNEs in these industries has been discouraged (Luo \& Park, 2001). Hence, this finding is line with China specific context, where traditional TCE logic may sometimes fail to provide answers due to specific characteristics of Chinese capitalism (Huang, 2008).

An interesting result concerns non-significance of international experience, while significance of target country experience $(\mathrm{p} \leq 0.05)$ for acquisition entry strategy of the Nordic MNEs in China. We would like to explain this finding by referring to the fact that although, general international experience may offer MNEs increased capabilities of managing subsidiaries across cultures and 
countries (Barkema et al., 1996; Larimo, 2003), this experience has less value for MNEs in emerging economies like China ( $\mathrm{Li} \&$ Meyer, 2009) due to their specific context as well as continuing transition to market economy. However, in such cases, target country experience becomes more important for MNEs. The regression results show that high target country experience lead to the choice of full acquisitions by Nordic MNEs, which is in line with our hypothesis 3 . This finding is in line with past IB studies that refer to knowledge acquisition of MNEs with prior investment experience in the target country and their less dependence on local partner (Hennart, 1991). Moreover, as most of the employees are still Chinese in the acquired firm, therefore, MNEs can still take advantage of local networks and integrate work practices with their global strategy (Dikova et al., 2010).

The regression results further depict that cultural distance is significant at $\mathrm{p} \leq 0.05$ level and high cultural distance lead to the choice of full acquisitions rather than partial acquisitions as hypothesized by us. We explain this finding by referring to the fact that cost and uncertainty in shared ownership structure are greater in culturally distant host countries due to volatility of the environment in the host country (Brouthers \& Brouthers, 2000), especially if it is a transition economy like China. Therefore, full acquisition in this case offered Nordic MNEs increased control over their subsidiaries in order to minimize transaction costs (Hill et al., 1990), as well as manage the subsidiary efficiently by integrating local work practices with global strategy (Meyer \& Altenborg, 2008) rather than dealing with problems associated with local partner in case of partial acquisition (Arslan \& Larimo, 2012).

The results further show that the level of product diversification of investing MNE is highly significant at $\mathrm{p} \leq 0.01$ level and highly diversified Nordic MNEs tended to choose full acquisitions rather than partial acquisitions as hypothesized by us. This finding can be explained by referring to the specific characteristics of acquisition entry mode that have been ignored in past IB studies mostly as they concentrated on either establishment or ownership mode strategies of MNEs. It has been referred in IB studies that when the degree of product diversification of the MNEs increase, the lack of product-specific knowledge in all fields of industries becomes evident which increases importance of having a partner in subsidiary management. Such product-specific knowledge is experiential and largely tacit (Slangen \& Hennart, 2007), and therefore it is costly to replicate such 
knowledge internally and hardly to purchase in market (Hennart, 1991). Hence, MNEs having more diversified operations may find collaborative entry modes being more efficient tool to access such product-specific knowledge as mentioned in the studies (e.g. Mudambi \& Mudambi, 2002; Larimo \& Arslan, 2013). However, in case of acquisition, investing Nordic MNEs already had access to local knowledge via the employees of acquired subsidiary. Therefore, their preference for full acquisition can be understandable as management of partial acquisition partnership in an emerging market economy can be problematic for Western MNEs (Meyer, 2002).

We further observe that timing of acquisition is mildly significant at $p \leq 0.10$ and the results show that investments made prior to 2001 tend to partial acquisition while later investments tend to be full acquisition. This result is in line with hypothesis 7 and as a result it is accepted. It is important to mention that post 2000, the market economy institutions strengthened as well as restrictions on acquisitions by the foreign MNEs slowly reduced that even some foreign MNEs were able to acquire some SOEs (Norton \& Chao, 2001) due to China's accession to WTOS. SOEs in China were suffered from low efficiency and huge losses. Moreover, as Chinese government imposed relatively little control over private enterprises since late 1990s, MNEs had a greater opportunity to acquire private enterprises in China (Teng, 2004). Hence, the propensity of recent acquisition of Nordic MNEs to be full acquisition is logical and in line with development and strengthening of market economy institutions in China.

Finally, the regression results also show that acquired subsidiaries located in SEZ's tend to be full acquisitions. This finding provides support for hypothesis 8 and hence, we accept it. As, mentioned earlier a key feature of institutional reforms and development of market economy in China has been development of open cities/special economic zones, where the restriction of foreign MNEs tended to be far lower than the rest of the country (Luo, 2000). Moreover, this finding also strengthens the findings of past IB studies where empirical supports for the positive relationship between subsidiaries located in SEZ/open coastal cities and the choice of full ownership mode has been found (e.g. Luo, 2001; Wei et al., 2005).

\section{IMPLICATIONS, LIMITATIONS AND FUTURE RESEARCH DIRECTIONS}


The purpose of the present study is to analyze the determinants of the choice between full and partial acquisitions of Nordic MNEs in China. Our analysis was based on a relatively unique dataset of 106 investments by 65 Nordic MNEs in China over 1987 to 2012. Drawing on the arguments from established IB theories of TCE, RBV and institutional theory, our study analyzed the determinants of acquisition entry strategy, i.e., choice of full vs. partial acquisition. We found that greater host country experience, high cultural distance, diversified parent MNEs, timing of investments (2002-2012) and subsidiary located in SEZs / OCCs are significant determinants of Nordic MNEs acquisition strategy. Our study pointed out that the amount of MNEs' prior experience in China significantly increases their preferences to choose full acquisitions. As discussed above, this may be explained that there is less need for Nordic MNEs having greater business experience in China to rely on local partners (Hennart, 1991). However, in a recent study by Arslan and Larimo (2012), Finnish parent MNEs' host country experience was not a significant determinant of full vs. partial acquisition strategy. Their sample contains investments made by selected emerging economies in CEE, Asia and Latin America, which we believe to be the reason for the difference between their result and our finding.

This study also supported the view that timing of acquisitions in China increases the probability of Nordic parent MNEs to choose full acquisitions. A similar finding was also found in the study by Arslan and Larimo (2012) that when investing in selected economies in CEE, Asia and Latin America, Finnish MNEs are more likely to opt for full acquisitions. This can be explained by the transitions from planned to market economy in China. In the earlier phase of transitions, full ownership was discouraged by Chinese government. Consequently, parent MNEs preferred to opt for partial ownership strategy to avoid unnecessary government interventions. We further found that investments located in SEZs and / or OCCs increased the probability of Nordic MNEs to opt for full acquisitions. This result supported the notion that preferential host government policies enacted in open areas appear to encourage Nordic MNEs to choose full acquisitions in China.

The result of our study has certain useful implications for the managers of Western and especially Nordic MNEs aspiring to enter Chinese market via acquisitions in the manufacturing sector. Firstly, it is important for them to analyze industry research and development intensity, target country experience, cultural distance, product diversification of MNEs, timing of acquisition and subsidiary location before making the decision concerning full or partial acquisition choice. Secondly, 
institutional advancement and subsequent relaxations concerning majority ownership for foreign firms offers a useful opportunity for these MNEs to fully acquire the target company in China, so that they can easily align acquired subsidiary to their international strategy and organizational practices.

Like all research projects, our study also has several limitations. Our study only included a sample of manufacturing investments made in China. Previous studies found that the determinants of entry mode strategy differ by types of industries, i.e., manufacturing and service industries (Brouthers \& Brouthers, 2003). Future studies are encouraged to include service firms in their empirical analysis. Further on, our study analyzed acquisition entry strategy in a single emerging country (China). There are different patterns of institutional changes among different transition economies (Demirbag et al., 2008). Therefore, we suggest that future research may incorporate other emerging markets especially in Asia into their research design based on key determinants identified in this study.

\section{ENDNOTES}

[1] According to OECD classifications, a branch is considered as high-tech if on average it spends at least 4 per cent of its value added for R\&D. A branch uses on average 1 to 4 per cent is classified as medium-tech. The rest are low-tech branches. The following branches are classified as high-tech using the statistics provided by Nordic Statistical Secretariat: SIC 2833-2834, 3573-3574, 3579, 36, 37, AND 38; Medium-tech branches are: all 28 except $2833 \&$ 2834, 30, 3339, 3341, 33563357, 3369, 35 except 3573-3574 and 3579, 39. The rest are classified as low-tech branches. [2] Special economic zones: Shenzhen, Zhuhai, Shantou in Guangdong province, Xiamen in Fujian province, and entire Hainan province. Open coastal cities: Yangtze River Delta, Pearl River Delta, Bohai Bay, Liaodong Peninsula, and Shandong Peninsula (Zhou, Delios, \& Yang, 2002).

\section{REFERENCES}

Amemiya, T. (1981). Qualitative response models: A survey. Journal of Economic Literature, 4(4), 1483-1536.

Anderson, E., \& Gatignon H. (1986). Modes of foreign entry: a transaction cost analysis and propositions. Journal of International Business Studies, 17(3), 1-26. 
Arslan, A., \& Larimo, J. (2012). Partial or full acquisitions: influences of institutional pressures on acquisition entry strategy of multinational enterprises. In M. Demirbag \& G. Wood (Eds.). Handbook of Institutional Approaches to International Business (pp. 320-343). UK: Edward Elgar.

Arslan, A. (2012). Impacts of institutional pressures and the strength of market supporting institutions in the host country on the ownership strategy of multinational enterprises: Theoretical discussion and propositions. Journal of Management and Governance, 16(1), 107-124.

Arslan, A., \& Larimo, J. (2011). Greenfield investments or acquisitions: Impacts of institutional distance on establishment mode choice of multinational enterprises in emerging economies" Journal of Global Marketing, 24(4), 345-356.

Arslan, A., \& Larimo, J. (2010). Ownership strategy of multinational enterprises and the impacts of regulative and normative institutional distance: Evidence from Finnish foreign direct investments in Central and Eastern Europe. Journal of East-West Business, 16(3), 179-200.

Barkema, H. G., Bell, J. H. J., \& Pennings, J. M. (1996). Foreign entry, cultural barriers, and learning. Strategic Management Journal, 17(2), 151-166.

Barney, J. (1991). Firm resources and sustained competitive advantage. Journal of Management, 17(1), 99-120.

Bartlett, C.A., \& Ghoshal, S. (1989). Managing Across Borders: The Transnational Solution. Boston: Harvard Business School Press.

Belsley, D. A., Kuh, E., \& Welsch, R.E. (1980). Regression diagnostics: Identifying influential data and sources of collinearity. New York: Wiley.

Brouthers, K. D., \& Brouthers, L. E. (2000). Acquisition or greenfield start-up? Institutional, cultural and transaction cost influences. Strategic Management Journal, 21(1), 89-97.

Brouthers, K. D., \& Brouthers, L. E. (2003). Why service and manufacturing entry mode choices differ: the influence of transaction cost factors, risk and trust. Journal of Management Studies, 40(5), 1179-1204.

Brouthers, K. D., \& Hennart, J. F. (2007). Boundaries of the firm: insights from international entry mode research. Journal of Management, 33(3), 395-425.

Burgel, O., \& Murray, G.C. (2000). The international market entry choices of start-up companies in high technology industries. Journal of International Marketing, 8(1), 33-62.

Chang, Y.C., Kao, M.S., Kuo, A. \& Chiu, C.F. (2012). How cultural distance influences entry mode choices: the contingent role of host country's governance quality. Journal of Business Research, 65(8), 1160-1170. 
Chen, S. F. (2008). The motives for international acquisitions: capability procurements, strategic considerations, and the role of ownership structures. Journal of International Business Studies, 39(3), 454-471.

Chen, S. F., \& Hennart, J-F. (2004). A hostage theory of joint ventures: why do Japanese investors choose partial over full acquisitions to enter the United States? Journal of Business Research, 57(10), 1126-1134.

Chen, H. Y., \& Hu, M.Y. (2002). An analysis of determinants of entry mode and its impact on performance. International Business Review, 11(2). 193-210.

Chiao, Y. C., Lo, F. Y., \& Yu, C. M. (2010). Choosing between wholly-owned subsidiaries and joint ventures of MNCs from an emerging market. International Marketing Review, 27(3), 338365.

Child, J., \& Tsai, T. (2005). The dynamic between firms' environmental strategies and institutional constraints in emerging economies: Evidence from China and Taiwan. Journal of Management Studies, 42(1), 95-125.

Chung, C. C., \& Beamish, P. W. (2005). The impact of institutional reforms on characteristics and survival of foreign subsidiaries in emerging economies. Journal of Management Studies, 42(1), $35-62$.

Claver, E., \& Quer, D (2005): Choice of market entry mode in China: the influence of firm-specific factors. Journal of General Management, 30(3), 51-70.

Datta, D. K., Herrmann, P., \& Rasheed, A. A. (2002). Choice of foreign market entry mode: Critical review and future directions. In M. A. Hitt \& Cheng, J. L. C. (Eds), Managing Transnational Firms: Resources, Market Entry and Strategic Alliances. Advances in International Management, (pp. 85153). Amsterdam: JAI Press.

Delios, A., \& Beamish, P.W. (1999). Ownership strategy of Japanese firms: transactional, institutional, and experience influences. Strategic Management Journal, 20(10), 915-933.

Delios, A., \& Henisz, W. J. (2003). Political hazards and the sequence of entry by Japanese firms, 1980-1998. Journal of International Business Studies, 34(3), 227-241.

Demirbag, M., Tatoglu, E., \& Glaister, K. W (2008). Factors affecting perceptions of the choice between acquisition and greenfield entry: the case of Western FDI in an emerging market, Management International Review, 48(1), 5-38.

Demirbag, M.,Tatoglu, E., \& Glaister K.W. (2009). Equity-based entry modes of emerging country multinationals: Lesson from Turkey. Journal of World Business, 44(4), 445-462. 
Demirbag, M., Apaydin, M., \& Tatoglu, E. (2011). Survival of Japanese subsidiaries in the Middle East and North Africa. Journal of World Business, 46(4), 411-425.

Dikova, D. (2012). Entry mode choices in emerging economies: the moderating effect of institutional distance on managers' personal experiences. Journal of East-West Business, 18(1), 127.

Dikova, D., \& van Witteloostuijn, A. (2007). Foreign direct investment mode choice: entry and establishment modes in transition economies. Journal of International Business Studies, 38(6), 1013-1033.

Dikova, D., Rao S. P., \& van Witteloostuijn A. (2010). Cross-border acquisition abandonment and completion: the effect of institutional differences and organizational learning in the international business service industry, 1981-2001. Journal of International Business Studies, 41(2), 223-245.

Dowell, G., \& Killaly, B. (2009): Effect of resource variation and firm experience on market entry decisions: evidence from U.S. telecommunication firm's international expansion decisions. Organization Science, 20(1), 69-84.

Drogendigk, R., \& Slangen, A.H.L. (2006). Hofstede, Schwartz, or managerial perceptions? The effects of different cultural distance measures on establishment mode choices by multinational enterprises. International Business Review, 15(4), 361-380.

Eden, L., \& Miller, S. (2004). Distance matters: Liability of foreignness, institutional distance and ownership strategy. In M. Hitt \& J. Cheng (Eds.), Theories of the multinational enterprise diversity, complexity and relevance advances in international management. (pp.187-221). New York: Elsevier.

Gatignon, H \& Anderson, E. (1988). The multinational corporation's degree of control over foreign subsidiaries: An empirical test of a transaction cost explanation. Journal of Law, Economics, and Organization, 4(2), 305-336.

Gomes-Casseres, B (1989). Ownership structures of foreign subsidiaries: Theory and evidence. Journal of Economic Behavior and Organization, 11(1), 1-25.

Gomes-Casseres, B. (1990). Firm ownership preferences and host government restrictions: an integrated approach. Journal of International Business Studies, 34(2), 185-198.

Gomes, L., \& Ramaswamy, K. (1999). An empirical examination of the form of the relationship between multinationality and performance, Journal of International Business Studies, 30(2), 173188. 
Hennart, J.F. (1982). A theory of the multinational enterprise. Ann Arbor: University of Michigan Press.

Hennart, J. F. (1991). The transaction costs theory of joint ventures: an empirical study of Japanese subsidiaries in the United States. Management Science, 37(4), 483--497.

Hennart, J. F., \& Park., Y. R. (1993). Greenfield vs. acquisition: the strategy of Japanese investors in the United States. Management Science, 39(9), 1054-1070.

Hennart J.F., \& Larimo J. (1998). The impact of culture on the strategy of multinational enterprises: Does national origin affect ownership decisions? Journal of International Business Studies, 29(3), 515-538.

Hill, C. L., Hwang, P., \& Kim, W. C. (1990). An eclectic theory of the choice of international entry mode. Strategic Management Journal, 11(2), 117-128.

Hofstede, G. (1990). Culture and organizations: Software of the mind. New York: McGraw-Hill.

Huang, Y. (2008). Capitalism with Chinese characteristics: Entrepreneurship and state during the reform era. New York: Cambridge University Press.

Jakobsen, K., \& Meyer, K. E. (2008). Partial acquisitions: the overlooked entry mode. In J. H. Dunning \& Gugler P. (Eds), Process in International Business Research. (pp. 2013-226). New York: Oxford University Press Inc.

Johanson, J., \& Vanlne, J.E. (1977). The internationalization process of the firm. A model of knowledge development and increasing foreign market commitment. Journal of International Business Studies, 8(1), 23-32.

Jung, J.C., Beamish, P.W., \& Goerzen, A. (2008). FDI ownership strategy: A Japanese-US MNE comparison, Management International Review, 48(5), 491-524.

Kaynak, E., Demirbag, M., \& Tatoglu, E. (2007). Determinants of ownership based entry mode choice of MNEs: Evidence from Mongolia, Management International Review, 47(4), 505-530.

Kobrin, S.J. (1991). An empirical analysis of the determinants of global integration. Strategic Management Journal, 12(Summer Special Issue), 17-32.

Kogut, B., \& Singh, H. (1988). The effect of national culture on the choice of entry mode. Journal of International Business Studies, 19(3), 412-432.

Larimo, J. (2003). Form of investment by Nordic firms in world markets. Journal of Business Research, 56(10), 791-803.

Larimo, J., \& Arslan, A. (2013). Determinants of Foreign Direct Investment Ownership Mode Choice: Evidence from Nordic Investments in Central and Eastern Europe, Journal for East European Management Studies, 18(2), 232-263. 
Li, P.Y., \& Meyer, K.E. (2009). Contextualizing experience effects in international business: A study of ownership strategies. Journal of World Business, 44(4), 370-382.

Li, J., Yang, J., \& Yue, D.R. (2007). Identity, community, and audience: how wholly owned foreign subsidiaries gain legitimacy in China. Academy of Management Journal, 50(1), 175-190.

Lin, H. (2000). Choice of Market Entry Mode in Emerging Markets: Influences on Entry Strategy in China. Journal of Global Marketing, 14(1/2), 111-127.

Lu, Y., Karpova, E. E., \& Fiore, A. M. (2011). Factors influencing international fashion retailers' entry mode choice. Journal of Fashion Marketing and Management, 15(1), 58-75.

Luo, Y. D. (2000). Multinational corporations in China. Hendon: Copenhagen Business School Press.

Luo, Y. D. (2001), Determinants of entry in an emerging economy: A multilevel approach, Journal of Management Studies, 38(3), 443-472.

Luo, Y.D., \& Park, S.H. (2001). Strategic alignment and performance of market-seeking MNCs in China. Strategic Management Journal, 22(2), 141-155.

Makino, S., \& Beamish, P.W. (1998). Performance and survival of joint ventures with nonconventional ownership structures. Journal of International Business Studies, 27(5), 905-927.

Meyer, K. E. (2002). Management challenges in privatization acquisitions in transitions economies. Journal of World Business, 37(4), 266-276.

Meyer, K. L., \&. Peng, M.W. (2005). Probing theoretically into Central and Eastern Europe: transactions, resources, and institutions. Journal of International Business Studies, 36(6), 600-621.

Meyer, K.E., \& Tran, Y.T.T. (2006). Market penetration and acquisition strategies for emerging economies. Long Range Planning, 39(2), 177-197.

Meyer, C. B., \& Altenborg, E. (2008). Incompatible strategies in international mergers: The failed merger between Telia and Telenor. Journal of International Business Studies, 39(3), 508-525.

Morschett, D., Schramm-Klein, H., \& Swoboda, B (2010). Decades of research on market entry modes: what do we really know about external antecedents of entry mode choice? Journal of International Management, 16(1), 60-77.

Mudambi, R., \& Mudambi, S.M. (2002). Diversification and market entry choices in the context of foreign direct investment. International Business Review, 11(1), 35-55.

Norton, P., \& Chao, H. (2001). Mergers and Acquisition in China. The Chinese Business Review, September-October, 46-53. 
Pablo, A. L., \& Javidan, M. (2004). Mergers \& Acquisitions: Creating integrative knowledge. Malden MA., Oxford: Blackwell Publishing.

Padmanabhan, P., \& Cho, K. R. (1996). Ownership strategy for a foreign affiliate: an empirical investigation of Japanese firms. Management International Review, 36(1), 45-65.Padmanabhan, P., \& Cho, K.R. (1999). Decision specific experience in foreign ownership and establishment strategies: evidence from Japanese firms. Journal of International Business Studies, 30(1), 25-41.

Palepu, K. (1985). Diversification strategy, profit performance and the entropy measure. Strategic Management Journal, 6(3), 239-255.

Pallant, J. (2007). SPSS survival manual: a step by step guide to data analysis using SPSS for windows. Buckingham: Open University Press.

Peng, M. W. (2003), Institutional transitions and strategic choices, Academy of Management Review, 28(2), 275-296.

Peng, M., Wang, D., \& Jiang, Y. (2008). An Institution-based View of International Business Strategy: A Focus on Emerging Economies. Journal of International Business Studies, 39(5), 920936.

Peng, M., \& Khoury, T.A. (2009). Unbundling the institution based view of international business strategy. In A. Rugman (Ed), The Oxford Handbook of International Business (2nd ed.), (pp. 256258). New York: Oxford University Press.

Shi, Y.Z., Ho, P.Y., \& Siu, W.S. (2001). Market entry mode selection: the experience of small Hong Kong firms investing in China. Asia Pacific Business Review, 8(1), 19-41.

Shimizu, K., Hitt M. A., Vaidyanath D., \& Pisano V. (2004). Theoretical foundations of crossborder mergers and acquisitions: a review of current research and recommendations for the future. Journal of International Management. 10(3), 307-353.

Slangen, A., \& Hennart, J. F. (2007). Greenfield or acquisition entry: a review of the empirical foreign establishment mode literature. Journal of International Management, 13(4), 403-429.

Slangen, A. \& Hennart, J.F. (2008): Do multinationals really prefer to enter culturally-distant countries through greenfields than through acquisitions? The role of parent experience and subsidiary autonomy. Journal of International Business Studies, 39(3), 472-490.

Sun, H. H. (1999): Entry modes of multinationals corporations into China's market: a socioeconomic analysis. International Journal of Social Economics, 26(5), 642-659.

Tallman, S., \& Fladmoe-Lindquist, K. (2002). Internationalization, globalization, and capabilitybased strategy. California Management Review, 45(1), 116-135. 
Taylor, C. R., Zhou, S., \& Osland, G. E. (1998). A transaction cost perspective on foreign market entry strategies of US and Japanese firms. Thunderbird International Business Review, 40(4), 389-412.

Teng, B. S. (2004), The WTO and entry mode choice in China, Thunderbird International Business Review, 46(4), 381-400.

Tihanyi, L., Johnson,R.A., Hoskisson, R.E., \& Hitt, M.A. (2003). Institutional ownership differences and international diversification: The effects of boards of directors and technological opportunity. Academy of Management Journal, 46(2), 195-238.

Tihanyi, L., Griffith, D., \& Russell, C. (2005). The effect of cultural distance on entry mode choice, international diversification and MNE performance: A meta-analysis. Journal of International Business Studies, 36(3), 270-283.

Wei, Y.G., Liu, B., \& Liu, X. M. (2005). Entry modes of foreign direct investment in China: a multinomial logit approach. Journal of Business Research, 58(11), 1495-1505.

Wetherill, G.B. (1986). Regression analysis with applications, London: Chapman and Hall.

Y.M., Lee, J., \& Kee, G. (2009). China's special economic zones at 30, Eurasian Geography and Economies, 50(2), 222-240.

Zhao, H. X., Luo, Y. D., \& Suh, T. (2004). Transaction cost determinants and ownership-based entry mode choice: a meta-analytical review. Journal of International Business Studies, 35(6), 524-544.

Zhou, C. H., Delios, A., \& Yang, J. Y. (2002). Locational determinants of Japanese foreign direct investment in China. Asia Pacific Journal of Management, 19(1), 63-86. 
TABLE 1: Summary of sample characteristics

Ownership structure:

Partial acquisitions (66), Full acquisitions (40)

Country of origin of investing MNEs:

Denmark=27, full acquisitions $=12$

Finland $=28$, full acquisitions $=9$

Norway $=15$, full acquisitions $=2$

Sweden $=36$, full acquisitions $=17$

Timing of investment:

1987-2001 (43) (full acquisitions=11),

2002-2012 (63) (full acquisitions=29)

Subsidiary location:

SEZs/open coastal cities (72) (full acquisitions=29)

Other cities (34) (full acquisitions=11)
Manufacturing industries (SIC 20-39):

Electronic (11), machinery (24), chemical (10), food (18), paper (10)

Parent's international experience:

Minimum (1), Maximum (182),

Mean (49.26)

Parent's target country experience:

Minimum (0), Maximum (15),

Mean (5.12)

Industry R\&D intensity of investing MNEs:

High-tech branch (22) (full acquisitions=8),

Medium-tech branch (36) (full acquisitions=14),

Low-tech branch (48) (full acquisitions=18) 


\section{TABLE 2. Operationalization of independent and control variables used in this study}

\begin{tabular}{|c|c|c|}
\hline VARIABLES & OPERATIONALIZATION & REFERENCE(S) \\
\hline \multicolumn{3}{|l|}{ Independent variables } \\
\hline Industry $\mathrm{R} \& \mathrm{D}$ intensity & $\begin{array}{l}\text { A classification of various 4-digit SIC industries into three } \\
\text { categories based on their value added figures }{ }^{1}\end{array}$ & $\begin{array}{l}\text { Larimo (2003); Dikova } \\
\text { and Witteloostuijn } \\
(2007)\end{array}$ \\
\hline International experience & $\begin{array}{l}\text { The number of foreign manufacturing investments made by } \\
\text { the company before the reviewed investment. }\end{array}$ & $\begin{array}{l}\text { Padmanabhan \& Cho } \\
\text { (1999); Larimo (2003); } \\
\text { Arslan and Larimo } \\
(2011,2012)\end{array}$ \\
\hline Target country experience & $\begin{array}{l}\text { The experience in years from the first manufacturing } \\
\text { investment of the firm in the target country. }\end{array}$ & $\begin{array}{l}\text { Hennart and Park } \\
\text { (1993); Padmanabhan } \\
\text { and Cho (1999); Larimo } \\
\text { (2003); Arslan and } \\
\text { Larimo (2011, 2012) }\end{array}$ \\
\hline $\begin{array}{l}\text { Cultural distance between home } \\
\text { and target country }\end{array}$ & $\begin{array}{l}\text { Cultural distance is measured by Kogut \& Singh (1988) } \\
\text { composite index, which is based on difference between Nordic } \\
\text { countries and China along four dimensions of culture } \\
\text { identified by Hofstede (1980). }\end{array}$ & $\begin{array}{l}\text { Brouthers and Brouthers } \\
\text { (2000); Larimo (2003); } \\
\text { Demirbag et al. (2008) }\end{array}$ \\
\hline $\begin{array}{l}\text { Economic growth in the target } \\
\text { country }\end{array}$ & $\begin{array}{l}\text { Economic growth (\% of GDP growth) in the target country of } \\
\text { the investment in the preceding the investment (UNCTAD) }\end{array}$ & $\begin{array}{l}\text { Hennart (1991); } \\
\text { Brouthers and Brouthers } \\
(2000) \text {; Arslan and } \\
\text { Larimo (2010, 2011, } \\
\text { 2012) }\end{array}$ \\
\hline $\begin{array}{l}\text { Degree of product } \\
\text { diversification }\end{array}$ & $\begin{array}{l}\text { The number of 4-digit SIC codes in which the company was } \\
\text { operating based on the annual reports and websites of the } \\
\text { firms. }\end{array}$ & $\begin{array}{l}\text { Hennart and Larimo } \\
\text { (1998); Mudambi and } \\
\text { Mudambi (2002). }\end{array}$ \\
\hline Timing of acquisition & $\begin{array}{l}\text { A dummy variable where } 1 \text { stands for investments made pre } \\
2002 \text { and } 0 \text { for after } 2001\end{array}$ & $\begin{array}{l}\text { Wei et al. (2005); Peng } \\
\text { (2003) }\end{array}$ \\
\hline $\begin{array}{l}\text { Subsidiary located in SEZs/open } \\
\text { coastal areas }\end{array}$ & $\begin{array}{l}\text { A dummy variable where } 1 \text { stands for subsidiaries located in } \\
\text { special economic zones (SEZs) and open coastal cities and } 0 \\
\text { for otherwise }^{2}\end{array}$ & Luo (2001) \\
\hline \multicolumn{3}{|l|}{ Control variables } \\
\hline Resource intensive industry & $\begin{array}{l}\text { A dummy variable where } 1 \text { indicates that the subsidiary's } \\
\text { main products are in a resource intensive industry and } 0 \text { for } \\
\text { other industries. }\end{array}$ & Hennart (1991) \\
\hline Industry restrictions & $\begin{array}{l}\text { A dummy variable where restricted manufacturing industries } \\
\text { in China are coded as } 1 \text { and encouraged manufacturing } \\
\text { industries are coded as } 0 .\end{array}$ & Chang et al. (2012) \\
\hline Industry concentration & $\begin{array}{l}\text { Compound growth rate in terms of number of firms over three } \\
\text { consecutive years prior to the establishment of the subsidiary. }\end{array}$ & Luo (2001) \\
\hline Industry sales growth & $\begin{array}{l}\text { Compound growth rate in terms of sales over three } \\
\text { consecutive years prior to the establishment of the subsidiary. }\end{array}$ & Luo (2001) \\
\hline Parent MNE size & $\begin{array}{l}\text { Worldwide annual sales of the company (in million euros) in } \\
\text { the year preceding the investment. }\end{array}$ & Taylor et al. (1998) \\
\hline
\end{tabular}

${ }^{1}$ See endnote $1 ;{ }^{2}$ See endnote 2 
TABLE 3. Binomial logistic regression estimates of acquisition strategy (full acquisition =1)

\begin{tabular}{|c|c|}
\hline Variable & Regression Coefficients \\
\hline R\&D intensity & $-0.900^{* *}$ \\
\hline International experience & -0.030 \\
\hline Target country experience & $0.069^{* *}$ \\
\hline Cultural distance & $1.920^{* *}$ \\
\hline Economic growth & -0.161 \\
\hline Product diversification of MNE & $0.162^{* * *}$ \\
\hline Timing of acquisition & $-1.703^{*}$ \\
\hline Subsidiary location & $0.367^{*}$ \\
\hline Industry resource intensity & $0.806^{* *}$ \\
\hline Industry restrictions & $-0.098^{*}$ \\
\hline Industry concentration & -4.4556 \\
\hline Industry sales growth & $1.310^{* *}$ \\
\hline Parent MNE size & 0.001 \\
\hline$N$ (full acquisitions) & $106(40)$ \\
\hline Model $x^{2}$ & $31.060^{* * *}$ \\
\hline-2 log likelihood & 119.942 \\
\hline Nagelkerke $R^{2}$ & 0.340 \\
\hline Correctly classified $(\%)$ & $70.8 \%$ \\
\hline
\end{tabular}

Levels of Significance: ${ }^{*} \mathrm{p} \leq 0.1,{ }^{* *} \mathrm{p} \leq 0.05,{ }^{* * *} \mathrm{p} \leq 0.01$ 
31

Appendix. Correlations between dependent, control and independent variables

\begin{tabular}{|c|c|c|c|c|c|c|c|c|c|c|c|c|c|c|c|c|c|c|c|c|}
\hline Variables & Mean & s.d. & 1 & 2 & 3 & 4 & 5 & 6 & 7 & 8 & 9 & 10 & 11 & 12 & 13 & 14 & 15 & 16 & 17 & 18 \\
\hline 1. ACQMODE & 0.45 & 0.50 & 1 & & & & & & & & & & & & & & & & & \\
\hline 2. ELECTRONIC & 0.10 & 0.31 & -0.06 & 1 & & & & & & & & & & & & & & & & \\
\hline 3. MACHINERY & 0.23 & 0.42 & 0.05 & -0.18 & 1 & & & & & & & & & & & & & & & \\
\hline 4. METAL & 0.07 & 0.25 & 0.14 & -0.09 & 0.14 & 1 & & & & & & & & & & & & & & \\
\hline 5. FOOD & 0.17 & 0.38 & $-0.21^{*}$ & -0.15 & $-0.25^{*}$ & -0.12 & 1 & & & & & & & & & & & & & \\
\hline 6. PAPER & 0.09 & 0.29 & -0.03 & -0.11 & -0.18 & -0.09 & -0.15 & 1 & & & & & & & & & & & & \\
\hline 7. INCONCEN & 0.07 & 0.08 & 0.08 & -0.00 & 0.10 & 0.03 & $-0.31^{* *}$ & -0.09 & 1 & & & & & & & & & & & \\
\hline 8. INGROWTH & 0.20 & 0.18 & 0.06 & -0.02 & 0.02 & -0.11 & -0.01 & -0.19 & $0.54^{* *}$ & 1 & & & & & & & & & & \\
\hline 9. RND & 1.75 & 0.78 & 0.02 & $0.55^{* *}$ & 0.17 & $-0.26^{* *}$ & $-0.44^{* *}$ & $-0.31^{* *}$ & 0.09 & 0.02 & 1 & & & & & & & & & \\
\hline 10. INTEXP & 49.80 & 38.39 & -0.09 & $-0.21^{*}$ & -0.06 & -0.11 & 0.18 & 0.10 & 0.18 & $0.28^{* *}$ & -0.19 & 1 & & & & & & & & \\
\hline 11. TCEXP & 5.21 & 4.40 & 0.10 & -0.14 & 0.02 & -0.13 & $0.20^{*}$ & 0.02 & $0.26^{* *}$ & $0.34^{*}$ & -0.17 & $0.64^{* *}$ & 1 & & & & & & & \\
\hline 12. CULTDIS & 5.24 & 0.81 & 0.00 & -0.14 & -0.03 & -0.18 & $0.25^{* *}$ & -0.31 & 0.08 & 0.05 & 0.02 & 0.13 & 0.14 & 1 & & & & & & \\
\hline 13. GDP & 9.55 & 2.00 & -0.14 & -0.08 & 0.07 & 0.22 & -0.15 & 0.00 & $0.40^{* *}$ & 0.18 & 0.01 & -0.12 & -0.16 & 0.15 & 1 & & & & & \\
\hline 14. DIVER & 10.37 & 7.21 & -0.05 & -0.21 & -0.11 & 0.01 & $0.23^{*}$ & 0.05 & -0.05 & 0.12 & -0.19 & $0.65^{* *}$ & $0.28^{* *}$ & -0.04 & -0.00 & 1 & & & & \\
\hline 15. PSIZE & 4780.41 & 4746.42 & 0.01 & -0.15 & -0.04 & -0.01 & -0.03 & 0.16 & 0.17 & 0.07 & -0.05 & $0.37^{* *}$ & $0.20^{*}$ & $0.27^{* *}$ & -0.03 & $0.21^{*}$ & 1 & & & \\
\hline 16. LOCATION & 0.68 & 0.47 & 0.10 & 0.17 & -0.11 & 0.18 & -0.17 & 0.01 & 0.01 & -0.13 & 0.07 & $-0.22^{*}$ & $-0.24^{*}$ & -0.08 & 0.04 & -0.17 & -0.00 & 1 & & \\
\hline 17. TIME & 0.41 & 0.49 & $-0.21^{*}$ & 0.03 & 0.01 & -0.07 & -0.07 & 0.06 & $-0.52^{* *}$ & $-0.35^{* *}$ & 0.06 & $-0.38^{* *}$ & $-0.63^{* *}$ & -0.01 & $0.19^{*}$ & -0.00 & -0.06 & $0.24^{*}$ & 1 & \\
\hline 18. RESTRICTION & 0.12 & 0.33 & -0.05 & -0.03 & 0.07 & 0.02 & -0.17 & -0.12 & 0.12 & 0.04 & $0.30^{* *}$ & 0.15 & -0.03 & 0.17 & -0.02 & 0.04 & $0.49^{* *}$ & 0.01 & 0.10 & 1 \\
\hline
\end{tabular}

